\title{
Introduction of Mycorrhizae Propagules and Rhizobium as Growth Promoter Legumes on Marginal Lands.
}

\author{
Tutik Nurhidayati, Dini Ermavitalini, Endang Purwanti Setyaningsih, and Agus Satriyono \\ Biology Department, Faculty of Mathematics and Natural Science, Institut Teknologi Surabaya \\ Kampus ITS KeputihSukolilo Surabaya JawaTimur \\ e-mail: tutik@bio.its.ac.id
}

\begin{abstract}
The objectives of this study is to evaluate the effect of mycorrhizae propagules and rhizobium on the growth on legume plants (Arachis hypogea) in marginal land. The experiment was conducted in Nguter village Lumajang, East Java. The results showed that mycorrhizae propagules stimulated rhizobium and plant growth by increasing plant height, dry weight and nodule weight. This results implied that mycorrhizae propagules stimulated and rhizobium were advantageous promoting growth at marginal lands.
\end{abstract}

Key words: Mycorhiza propagul, Rhizobium, legume and Marginal land

\section{INTRODUCTION}

Problem faced by Multi Agro Makmur village Nguter Pasirian Lumajang District is the critical of land. This is caused by the monoculture system, low water availability, as well as the use of inorganic fertilizers. As a result of these conditions damaged to the biological status of the soil, chemical and physical. Degraded ecosystems should be immediately treated by LCC ( Legume Cover Crops )

LCC is a method of processing techniques that are environmentally friendly land in sustainable agriculture. Advantages using this technique are 1) suppress the growth of weeds, thus saving the cost of weed control while still immature, (2) Increasing soil organic matter content, (3) improve the physical condition of the soil is aerated and maintain soil moisture, (4) prevent and reduce soil erosion, (5) binding (fixation) of nutrient nitrogen from the air, thus enriching the soil with nitrogen compounds and (6) suppress the growth of certain pests and diseases.

The LCC method is related to the use of legumes as an essential component of sustainable ecosystems (Subaksa, 2002). Arachis hypogea is one of legume plant symbiotic root nodules formed by Rhizobium and Arbuscula mycorrhizal symbiosis. Plant symbiosis with Rhizobium bacteria able to sewed free N2 from the air, reducing the uptake of $\mathrm{N}$ from the soil and beneficial to plants. Nodule formation and embedding of N2 from the air is very responsive to the uptake of phosphorus, so that Rhizobium infection in plants may provide a greater opportunity for arbuscula mycorrhizal colonization and colonization of other soil microbes on plant root system. Arbuscula Mycorrhizae Symbiosis able to increase the absorption of phosphorus from the form is not available to the form is available. Phosphorus can be used for activities of Rhizobium and plant growth (Paulitz and Linderman, 1991). Nitrogenase enzyme at high phosphorus content will be able to binding N2 higher. Nitrogen generated from N2-free fixation of the air is absorbed by arbuscula mycorrhizal and used by plants for growth and development (Naiola, 1996). On the other hand the plant will provide the fotoasimilat 
carbon compounds as a source of free energy for N2 fixation and vegetative growth arbuscula mycorrhizal (Killham, 1994). So that are a potential microbial biofertilizer and Rhizobium serves as mikorhiza stimulate growth of Arachis hypogea through the acceleration cycle of soil chemistry, producing compound growth promoter (hormone) and increases plant resistance to extreme conditions through cell turgor regulation and transport of nutrients ( Dixon, 2000).

\section{MATERIALS AND METHODS}

\section{Land Preparation For Application Methods LCC}

The area of land to be used is cleaned of weeds and is done land management. Further basic fertilizer was given for three days. The land area is made array with a distance of $50 \mathrm{~cm}$

\section{Seed Preparation for LCC and Rhizobium inoculation}

Seed crop is Arachis hypogeal. Seeds soaked in warm water. Furthermore rhizobium inoculated seed (10 grams of rhizobium in 0.25 liters of water for every $10 \mathrm{~kg}$ of mixed nuts). Seeds that had been inoculated rhizobium ready for use as seed. (Rodriqueez, 1997).

Planting Plants to LCC and Inoculation of VAM

Seeds ready to be planted on the sample plots. Each planting hole inoculated mycorrhizal.

\section{RESULT AND DISCUSSION}

Results of plant growth (height, weight nodule and plant dry weight) showed significantly different from control. The mean growth of peanut plants grown on marginal land shown in the table below:

Table 1. The Mean Plant Height peanuts in Control and treatment plants

\begin{tabular}{lllll}
\hline $\begin{array}{l}\text { Treatment } \\
\begin{array}{l}\text { The growth } \\
\text { parameters }\end{array}\end{array}$ & P1 & P2 & P3 & P4 \\
$\begin{array}{l}\text { Height } \\
\text { Crop }\end{array}$ & $17,6^{\mathrm{b}}$ & $21,3^{\mathrm{a}}$ & $26,6^{\mathrm{a}}$ & $26,3^{\mathrm{a}}$ \\
\hline
\end{tabular}

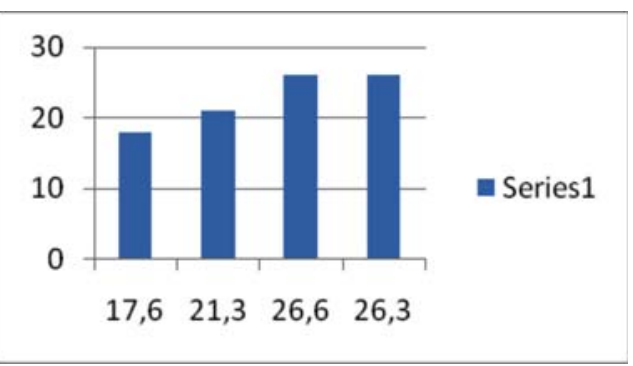

Figure 1. The Height mean peanut plants in Marginal land
Table 2. The mean weight nodule Peanut Plant Roots In the control plants and soil treatment

\begin{tabular}{lllll}
\hline $\begin{array}{l}\text { Treatment } \\
\text { The growth }\end{array}$ & $\mathrm{n}$ & $\mathrm{P} 2$ & $\mathrm{P} 3$ & $\mathrm{P} 4$ \\
parameters & & & & \\
\hline $\begin{array}{l}\text { Weight } \\
\text { nodule }\end{array}$ & $2^{\mathrm{b}}$ & $17^{\mathrm{a}}$ & $24^{\mathrm{a}}$ & $18^{\mathrm{a}}$ \\
Plant root & & & & \\
\hline
\end{tabular}

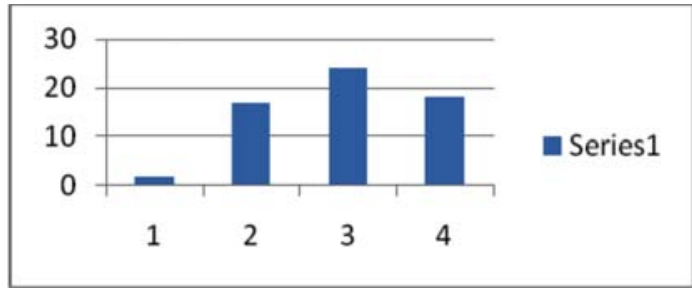

Figure 2. Weight Nodule Plant Root Peanut Mean in Marginal land 
Table 3. The mean dry weight Peanut Plant In the control plants and soil treatment

\begin{tabular}{|c|c|c|c|c|}
\hline $\begin{array}{l}\text { Treatment } \\
\text { The growth } \\
\text { parameters }\end{array}$ & P1 & P2 & P3 & P4 \\
\hline $\begin{array}{l}\text { dry weight } \\
\text { Peanut Plant }\end{array}$ & $0,67^{a}$ & $2,32^{a}$ & $1,71^{\mathrm{a}}$ & $2,09^{a}$ \\
\hline
\end{tabular}

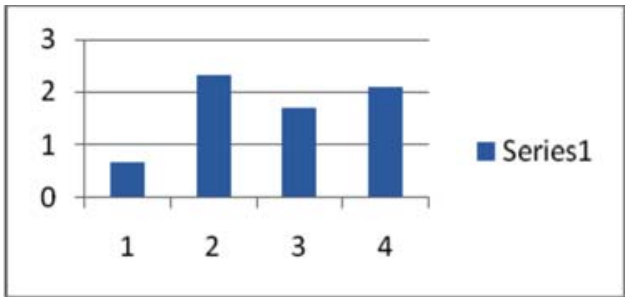

Figure 3. The mean dry weight Peanut Plant in Marginal land

\author{
Description \\ Treatmen 1 : Control \\ Treatmen 2 : Application mycorrhizal. \\ Treatmen 3 : Application Rhizobium \\ Treatmen 4 : Application mycorrhizal and Rhizobium
}

Results of plant growth (height, weight nodule and plant dry weight) showed significantly different from control. Treatment plant growth higher than the control due to the role of exogenous microbes that Rhizobium and mikorhiza. This increase may occur because of the tripartite relationship of mutual benefit between exogenous microbes with host plants. Results are assumed to increase with an increase in dry weight associated with the results of the piled in plant photosynthesis. Furthermore requirements for microbial energy from the host plant will increase microbial colonization. Microbial colonization (mycorrhizal and rhizobium) will provide a positive role in the supply of nutrients, especially $\mathrm{N}$ and $\mathrm{P}$ elements and water. Nitrogen elements act directly in the growth of plants, which generally is required for vegetative plant parts such as leaves, stems and roots (Sutedjo, 1991). Thus the presentation of $\mathrm{N}$ through Rhizobium inoculation can improve plant growth. This was caused by the beneficial tripartite relationship between them. The tripartite mycorrhizal relationship with the plant have been started in the absorption macro nutrients (especially of $\mathrm{N}$ ), micro nutrients and water. Furthermore the mycorrhizal infection in the roots of host plants affected, causing changes in the morphology, physiology and spending root exudates. Changes in the plant will affect other microbial populations, such as Rhizobium in the rhizosphere of host. Leguminosae plant is a plant that is very robust in the use of elements of P. Phosphorus is needed in N2 fixation in root nodules of plants Leguminosae (Paulitz \& Linderman, 1991). The same was said by Larcher (1995) that the high phosphorus requirements required by the root nodules for N2 fixation, whereas mycorrhizal requires large amounts of nitrogen for the synthesis of the cell wall, and both require a source of energy for the carbon compounds from the host plant. Tripartite symbiosis may provide synergistic growth response in the host plant when rhizobium and mycorrhiza each provide sufficient nutrients.

\section{CONCLUSION}

The results showed that mycorrhizae propagules stimulated and rhizobium plant growth: (to increase plant height, dry weight, nodul weight), which implies that mycorrhizae propagules stimulated and rhizobium were advantageous promoting growth at marginal lands. 


\section{REFERENCES}

Dixon, R.K., V.K. Garg, and M.V. Rao. 1993. Inoculation of Leucaena and Prosopis Seedlings with Glomus and Rhizobium Species in Saline Soil: Rhizosphere Relations and Seedlings Growth. Arid Soil Res Rehabil 7:133-144.

Heuer, B. 1994. Osmoregulatory Role of Proline in Water and Salt Stressed Plants In: Pessarakhli, M (Ed). Handbook of plant and Crop Stress. Marceel Dekker. Inc. New York. 363-382

Killham, K, 1994. Soil ecology. Cambridge University Press

Larcher, W. 1995. Physiological Plant Ecology. Second Totality Revised ed. In: M.A. Biderman-Thorson. Springer-Verlag. Berlin:303

Naiola, B.P. 1996. Regulasi Osmosis Pada Tumbuhan Tinggi. Hayati 3(1):01-06

Paulitz, T.C., and R.G. Linderman. 1991. Mycorrhyzal Interaction with Soil Organisms. In: D.K. Arora et al. (Eds.). Handbook of Applied Mycology: Soil and Plants, Volume 1. Marcel dekker, Inc. New York.

Subaksa, I.G.M. 2002. Pemanfaatan Mikoriza Untuk Penanggulangan Lahan Kritis. Makalah Falsafah Sains (PPs 702). Edisi April 2002. Program Pasca Sarjana / S3 Institut Pertanian Bogor. igmsubiksa@yahoo.com

Rodriqueez, H.G., J.K.M. Robert, W.R. Jordan, and M.C. Drew. 1997. Growth, Water Relations And Accumulation of Organic And Inorganic Solutes in Roots of Maize Seedling During Salt Strees. Plant Physiol Journal. 113: 881-893

Suardi, D., and A. Buang. 2003. Padi Liar Tetua Toleran Kekeringan. Buletin Plasma Nutfah Vol.9 No.1

Suhardi.1990. Pedoman Kuliah Mikoriza V.A. Proyek Peningkatan Perguruan Tinggi Universitas Gadjah Mada. PAU Bioteknologi Universitas Gadjah Mada. Yogyakarta. 